\title{
Current Knowledge and Awareness among Paedodontists of Maharashtra Regarding Prevention of Infective Endocarditis
}

\author{
Meghna Jayakar Padubidri ${ }^{1}$, Samarpita Swain ${ }^{2}$, Ekta Pankaj Kumar Srivastava ${ }^{3}$, \\ Sanket Pramod Kumar ${ }^{4}$, Cerin Susan Thomas ${ }^{5}$, Preetam Appasaheb Mahagaonkar ${ }^{6}$ \\ ${ }^{1}$ Department of Paediatric and Preventive Dentistry, Rural Dental College, Pravara Institute of \\ Medical Sciences, Loni, Maharashtra, India. ${ }^{2}$ Rural Dental College, Pravara Institute of Medical \\ Sciences, Loni, Maharashtra, India. ${ }^{3}$ Department of Paediatric and Preventive Dentistry, SMBT Dental \\ College and Hospital, Ghulewadi, Sangamner, Maharashtra, India. ${ }^{4}$ Perfect 32 Dental Care, Bettiah, \\ Bihar, India. ${ }^{5}$ Paediatric Dentist, Vellore, Kottayam, Kerala, India. ${ }^{6}$ Department of Prosthodontics, \\ SMBT Dental College and Hospital, Ghulewadi, Sangamner, Maharashtra, India.
}

\section{ABSTRACT}

\section{BACKGROUND}

Infective endocarditis is an infection of the endothelium of heart and heart valves with serious and fatal complications that often requires long-term treatment. Bacteraemia is considered to be an important step for the onset of infective endocarditis (IE) and mainly induced by invasive dental treatments, including tooth extraction, periodontal surgery, scaling and root planing. The purpose of this study was to evaluate the knowledge among the paedodontists concerning the preventive measures for infective endocarditis and to spread the awareness about the same, thus filling the clinical practice gap between dentists and cardiologists by helping in making collaborative decisions.

\section{METHODS}

A questionnaire survey was given to the paedodontists in India in order to collect information regarding their current common knowledge about infective endocarditis and for the future construction of an approach to improve this situation.

\section{RESULTS}

$68.4 \%$ of the paedodontists taking the survey preferred giving antibiotic prophylaxis mainly orally whereas $21.1 \%$ preferred to give it orally rather than IV and $10.5 \%$ of them preferred IV rather than oral. None of them preferred giving antibiotics intravenously. With regard to the type of antibiotics preferred, most preferred was oral amoxicillin (89.5\%) and other antibiotics were (10.5\%); whereas, no one preferred IV ampicillin. $89.5 \%$ of our respondents felt that antibiotic prophylaxis was definitely needed whereas $10.5 \%$ of them felt that it was partially needed.

\section{CONCLUSIONS}

Practitioners, cardiologists and the dentists need to discuss the potential benefits and also the harm of antibiotic prophylaxis with their patients before a decision is made about antibiotic administration.

\section{KEY WORDS}

Infective Endocarditis, Paedodontists, Cardiologists
Corresponding Author:

Dr. Meghna Jayakar Padubidri, Senior Lecturer,

403 - Department of Paediatric and Preventive Dentistry, Rural Dental College, Pravara Institute of Medical Sciences (DU), Ahmednagar, Rahata, Loni (BK)- 413736.

Maharashtra, India.

E-mail: meghna.jsp@gmail.com

DOI: $10.14260 /$ jemds/2021/257

How to Cite This Article:

Padubidri MJ, Swain S, Srivastava EP, et al. Current knowledge and awareness among paedodontists of Maharashtra regarding prevention of infective endocarditis. $J$ Evolution Med Dent Sci 2021; 10(17):12031207, DOI: $10.14260 /$ jemds/2021/257

Submission 20-12-2020,

Peer Review 24-02-2021,

Acceptance 01-03-2021,

Published 26-04-2021.

Copyright (C) 2021 Meghna Jayakar Padubidri et al. This is an open access article distributed under Creative Commons Attribution License [Attribution 4.0 International (CC BY 4.0)] 


\section{BACKGROUND}

Infective endocarditis a life-threatening condition that occurs in patients with underlying heart disease and is mainly caused by bacteraemia which is induced by invasive dental treatment. ${ }^{1}$ Due to this, there forms a bacterial mass termed vegetation on damaged heart valves, leading to severe valvular dysfunction. ${ }^{2}$ The aortic valve is more frequently affected, followed by mitral valve, whereas tricuspid valve involvement is considered to be rare. ${ }^{3}$ Repeated attacks of endocarditis reduce the 5-year survival of patients to $60 \% .{ }^{4}$ The most common causative organisms of IE reported in Japan were oral streptococci, followed by staphylococci indicating that prevention of IE should be considered by collaborative discussions between dentists and cardiologists. ${ }^{5-7}$

Bacteraemia is induced by invasive dental procedures, such as tooth extraction and periodontal surgery, and antibiotic prophylaxis is given prior to performing dental procedures to the patients at risk of IE. ${ }^{8-10}$ The initial guidelines for prevention of IE were proposed in 1955 by the American Heart Association (AHA), then modified based on clinical and scientific evidence, with the most recent published in 2007 (AHA 2007). ${ }^{11}$ Lauber showed clinicians are not always aware of current clinical guidelines, whereas dentists and physicians exhibit different patterns regarding antibiotic prescription. Dentists were more familiar than physicians with current American Heart Association (AHA) protocols. ${ }^{12}$ The changes that were elaborated in AHA 2007 were that prior to dental procedures, prophylaxis is considered reasonable only for those patients with underlying cardiac conditions associated with the highest risk of an adverse outcome, as well as for procedures involving manipulation of gingival tissue or the periapical region of the teeth in such patients. ${ }^{11}$

In the present study, we performed a survey to evaluate the knowledge of paedodontists with regards to association between dental procedures and the acquisition of infective endocarditis. Also, to focus on antibiotic prophylaxis for prevention of infective endocarditis.

\section{METHODS}

A questionnaire survey was given to the paedodontists in India in order to collect information regarding their current common knowledge about infective endocarditis and for the future construction of an approach to improve this situation.

This study was carried out electronically due to Covid constraints. A preformed structured questionnaire was distributed to paedodontists across the country from January 2020 to August 2020. Amongst the questionnaires distributed, 200 participants responded, and thus 200 completed questionnaires were considered for the study, which were then analysed. A preformed structured questionnaire was prepared which consisted the data such as the high-risk factors, the timing, the mode and the type of antibiotics etc. The subjects were informed about the purpose of the study and that their information was kept confidential.

\section{Statistical Analysis}

Data was entered in Microsoft Excel sheet and then transferred to Epi Info Software (7.1) and analysed.
RESULTS

$47.4 \%$ of our respondents have been practicing for less than 2 years, $21.1 \%$ for 2 - 5 years, $15.8 \%$ for 5 - 10 years and 15.8 $\%$ for more than 10 years. $42.1 \%$ of the paedodontists selected rheumatic heart disease (RHD) as the high-risk factor for infective endocarditis, whereas $26.32 \%$ have chosen congenital heart disease (CHD), $21.05 \%$ have chosen pacemaker as a risk and $10.53 \%$ have chosen mitral valve prolapse with regurgitation. There are none who felt that atrial and mitral septal defect can be a risk factor.

\begin{tabular}{|c|c|c|}
\hline Questions & Response & Percentage $\%$ \\
\hline \multirow{4}{*}{$\begin{array}{l}\text { Since how many years } \\
\text { have you been } \\
\text { practicing? }\end{array}$} & Less than 2 years & 47.37 \\
\hline & 2 - 5 years & 21.05 \\
\hline & $5-10$ years & 15.79 \\
\hline & 10 years or more & 15.79 \\
\hline \multirow{6}{*}{$\begin{array}{l}\text { What risk factors do } \\
\text { you consider to be high } \\
\text { risks for infective } \\
\text { endocarditis? }\end{array}$} & Congenital heart disease & 26.32 \\
\hline & Rheumatic heart disease & 42.11 \\
\hline & $\begin{array}{l}\text { Mitral value prolapses with } \\
\text { regurgitation }\end{array}$ & 10.53 \\
\hline & Pacemaker & 21.05 \\
\hline & Atrial septal defect & 0.00 \\
\hline & Mitral septal defect & 0.00 \\
\hline \multirow{4}{*}{$\begin{array}{l}\text { What kind of dental } \\
\text { treatment requires } \\
\text { prophylactic } \\
\text { antibiotics? }\end{array}$} & Filling & 0.00 \\
\hline & Tooth extraction & 89.47 \\
\hline & Pulpotomy & 5.26 \\
\hline & Scaling & 5.26 \\
\hline \multirow{3}{*}{$\begin{array}{l}\text { What is the timing for } \\
\text { antibiotics } \\
\text { prescription? }\end{array}$} & Before treatment in days & 26.32 \\
\hline & Immediately & 73.68 \\
\hline & After treatment in days & 0.00 \\
\hline \multirow{4}{*}{$\begin{array}{l}\text { How do you perform } \\
\text { antibiotic prophylaxis? }\end{array}$} & Mainly IV & 0.00 \\
\hline & IV rather than oral & 10.53 \\
\hline & Oral rather than IV & 21.05 \\
\hline & Mainly oral & 68.42 \\
\hline \multirow{3}{*}{$\begin{array}{c}\text { What type of antibiotics } \\
\text { do u use for antibiotics } \\
\text { prophylaxis? }\end{array}$} & Oral amoxicillin & 89.47 \\
\hline & IV ampicillin & 0.00 \\
\hline & $\begin{array}{l}\text { Others (macrolides, } \\
\text { azithromycin, tetracycline) }\end{array}$ & 10.53 \\
\hline \multirow{3}{*}{$\begin{array}{l}\text { Do you think antibiotics } \\
\text { prescription is } \\
\text { necessary for } \\
\text { prevention of infective } \\
\text { endocarditis? }\end{array}$} & Definitely needed & 89.47 \\
\hline & Partially needed & 10.53 \\
\hline & Not needed at all & 0.00 \\
\hline \multirow{3}{*}{$\begin{array}{l}\text { How many cases of } \\
\text { infective endocarditis } \\
\text { have you encountered } \\
\text { during your practice? }\end{array}$} & $0-10$ & 89.47 \\
\hline & $10-20$ & 10.53 \\
\hline & 20 or more & 0.00 \\
\hline \multirow{2}{*}{$\begin{array}{l}\text { Are you or your clinic } \\
\text { equipped to manage an } \\
\text { emergency case of } \\
\text { infective endocarditis? }\end{array}$} & Yes & 57.89 \\
\hline & No & 42.11 \\
\hline \multirow{4}{*}{$\begin{array}{l}\text { What training is } \\
\text { required to manage } \\
\text { cardiac patients? }\end{array}$} & BLS, no ACLS & 5.26 \\
\hline & BLS and ACLS & 89.47 \\
\hline & ICU & 5.26 \\
\hline & None of the above & 0.00 \\
\hline \multicolumn{3}{|c|}{ Table 1. Results of Our Study } \\
\hline
\end{tabular}

With regards to the dental treatment that requires prophylactic antibiotics, tooth extraction was the most preferred answer $(89.5 \%)$ followed by pulpotomy and scaling both being $5.26 \%$. Tooth filling wasn't chosen by any of our respondents. Regarding the timing of antibiotics prescription, majority of paedodontists $(73.7 \%)$ preferred giving antibiotics immediately before the treatment and $26.3 \%$ preferred giving antibiotics few days before treatment, 
whereas there was no response for giving it after treatment. $68.4 \%$ of paedodontists taking the survey preferred giving antibiotic prophylaxis mainly orally whereas $21.1 \%$ preferred to give it oral rather than IV and $10.5 \%$ of them preferred IV rather than oral. None of them preferred giving antibiotics mainly IV. With regards to the type of antibiotics preferred, the most preferred was oral amoxicillin (89.5\%) and others were $(10.5 \%)$ whereas no one preferred IV ampicillin. $89.5 \%$ of our respondents feel that antibiotic prophylaxis is definitely needed whereas $10.5 \%$ of them felt that it is partially needed. None of them were in support of not needing the antibiotics at all. $89.5 \%$ of our paedodontists have encountered 0 - 10 cases and the rest have encountered between $10-20$ cases in their practice. $89.5 \%$ of our respondents have chosen both basic life support (BLS) and advanced cardiovascular life support (ACLS) while $5.26 \%$ each have chosen BLS, no ACLS and intensive care unit (ICU) respectively. $57.9 \%$ of our paedodontists said that / their clinics were equipped to manage any emergency cases of infective endocarditis while the rest (42.1\%) weren't.

\section{DISCUSSION}

It is imperative to be aware of the presence of heart disease in patients prior to dental treatment. When a cardiologist refers the patient then the condition is generally known. However, such cases are speculated to be less, as patients often visit dentists directly without any referral. Therefore, education regarding the risk for infective endocarditis (IE) caused by dental treatments is important for at-risk patients. ${ }^{1}$ While some dental procedures and some specific cardiac problems are well recognised to be a clear indication for antibiotic prophylaxis in prevention of IE; there is still some controversy over other dental treatments as to prophylaxis has to be taken or not. ${ }^{13}$

In our study, the major risk factor considered by our respondents was rheumatic heart disease whereas none of them considered atrial and mitral septal defects to be a risk factor. The results of a study by Hashemipour et al. showed that previous bacterial endocarditis, rheumatic heart disease, and mitral valve prolapse with valvular regurgitation were diagnosed by dentists to be the most common conditions that needed antibiotic prophylaxis. ${ }^{14}$ Ventricular septal defects (VSD) accounts for $28.3 \%$, whereas atrial septal defect (ASD) $(6.7 \%) .{ }^{15}$ With regards to antibiotic prophylaxis for dental treatment, tooth extraction, pulpotomy and scaling were considered as risk in that particular order whereas tooth filling wasn't considered as risky in our study. In a study between one-step formocresol pulpotomy and bacteraemia, a $4 \%$ incidence of bacteraemia was found, although the authors pointed out that this is lesser than most other dental procedures and roughly equivalent to the reported frequency of spontaneous bacteraemia.16 Baumgartner et al. (1977) found a detectable bacteraemia in only one of the 30 patients undergoing nonsurgical root canal treatment, with an incidence of $3.3 \%$ as opposed to $83.3 \%$ following flap retraction, $33.3 \%$ following periapical curettage and $100 \%$ following dental extraction. ${ }^{17}$ It appears that the majority of dentists would not use ultrasonic scalers in the management of periodontal disease in patients fitted with a pacemaker or an implantable cardiac defibrillator (ICD). ${ }^{18}$

\begin{tabular}{|cc|}
\hline Procedure & Percentage \% \\
Baseline rate & 9 \\
Intraligamentary injection & 96.6 \\
Multiple extractions (4) & 51 \\
Single extraction & 39 \\
Mucoperiosteal flap & 39 \\
Tooth brushing & 38.5 \\
Matrix band placement with wedge & 32 \\
Rubber dam placement & 29.4 \\
Ultrasonic scaling of teeth & 252 \\
Polishing teeth & 24.5 \\
Slow-speed drill & 13 \\
High speed drill & 4 \\
\hline Table 2. Incidence of Bacteraemia Noticed \\
Following Various Dental Procedure $\mathbf{1 9}^{\mathbf{9}}$ \\
\hline
\end{tabular}

\begin{tabular}{|c|c|c|}
\hline $\begin{array}{c}\text { American Heart } \\
\text { Association }\end{array}$ & $\begin{array}{c}\text { British Society } \\
\text { for } \\
\text { Antimicrobial } \\
\text { Chemotherapy }\end{array}$ & British Cardiac Society \\
\hline $\begin{array}{l}\text { Manipulation of gingival, } \\
\text { periodontal and } \\
\text { periapical tissues; } \\
\text { incision of mucosa } \\
\text { including: } \\
\text { Surgery, periodontal } \\
\text { procedures, endodontic } \\
\text { instrumentation beyond } \\
\text { the apex or apical } \\
\text { surgery } \\
\text { Subgingival placement of } \\
\text { antibiotic fibre or strip, } \\
\text { initial placement of } \\
\text { orthodontic } \\
\text { bands but not brackets, } \\
\text { intraligamentary local } \\
\text { anaesthetic } \\
\text {-prophylactic cleaning of } \\
\text { teeth or implants where } \\
\text { bleeding is anticipated } \\
\text { Excluding: local } \\
\text { anaesthetic placement } \\
\text { (unless through site } \\
\text { of infection) }\end{array}$ & $\begin{array}{l}\text { Dental procedures } \\
\text { involving } \\
\text { dentogingival } \\
\text { manipulation and } \\
\text { endodontics. } \\
\text { A risk assessment, } \\
\text { which involves the } \\
\text { patient, is } \\
\text { important and } \\
\text { factors like the oral } \\
\text { hygiene status of } \\
\text { the patient are } \\
\text { important } \\
\text { considerations for } \\
\text { deciding } \\
\text { On prophylaxis. }\end{array}$ & $\begin{array}{l}\text { Examination procedures, } \\
\text { periodontal probing } \\
\text { Investigation procedures, } \\
\text { sialography } \\
\text { Anaesthetic procedures- } \\
\text { intra-ligamental local } \\
\text { anaesthesia } \\
\text { All surgical procedures } \\
\text { Restorative procedures } \\
\text {-rubber dam placement- } \\
\text { matrix band and wedge } \\
\text { placement-gingival } \\
\text { retraction cord placement } \\
\text { Periodontal procedures- } \\
\text { Professional cleaning } \\
\text { procedures-polishing teeth } \\
\text { with a rubber cup } \\
\text {-oral irrigation with water } \\
\text { jet-scaling, root planning } \\
\text {-antibiotic fibres or strips } \\
\text { placed sub gingivally } \\
\text { Endodontic procedures- } \\
\text { root canal instrumentation } \\
\text { beyond the root apex- } \\
\text { Avulsed tooth } \\
\text { reimplantation } \\
\text { Orthodontic procedures- } \\
\text { tooth separation } \\
\text {-exposure or exposure and } \\
\text { bonding } \\
\text { of tooth or teeth }\end{array}$ \\
\hline \multicolumn{3}{|c|}{$\begin{array}{l}\text { Table 3. Dental Procedures for Which Antibiotic } \\
\text { Prophylaxis is Recommended. }{ }^{20}\end{array}$} \\
\hline
\end{tabular}

\begin{tabular}{|c|c|c|c|}
\hline & & & $\begin{array}{l}\text { Regimen: Single } \\
\text { Dose } 30 \text { - } 60 \mathrm{~min} \\
\text { before the } \\
\text { Procedure }\end{array}$ \\
\hline Situation & Agent & Adults & Children \\
\hline Oral & Amoxicillin & $2 \mathrm{~g}$ & $50 \mathrm{mg} / \mathrm{kg}$ \\
\hline $\begin{array}{l}\text { Unable to take } \\
\text { oral medication }\end{array}$ & $\begin{array}{l}\text { Ampicillin or } \\
\text { Cefazolin } \\
\text { Ceftriaxone }\end{array}$ & $\begin{array}{c}2 \mathrm{~g} \mathrm{IM} \\
\text { or IV } \\
\text { 1g IM or IV }\end{array}$ & $50 \mathrm{mg} / \mathrm{kg}$ IM or IV \\
\hline $\begin{array}{c}\text { Allergic to } \\
\text { penicillin or } \\
\text { ampicillin-oral }\end{array}$ & $\begin{array}{l}\text { Cephalexin } \\
\text { or } \\
\text { Clindamycin } \\
\text { or } \\
\text { Azithromycin or } \\
\text { Clarithromycin }\end{array}$ & $\begin{array}{c}2 \mathrm{~g} \\
600 \mathrm{mg} \\
500 \mathrm{mg}\end{array}$ & $\begin{array}{l}50 \mathrm{mg} / \mathrm{kg} \\
20 \mathrm{mg} / \mathrm{kg} \\
25 \mathrm{mg} / \mathrm{kg}\end{array}$ \\
\hline \multirow[t]{2}{*}{$\begin{array}{l}\text { Allergic to } \\
\text { penicillin or } \\
\text { ampicillin oral } \\
\text { and unable to } \\
\text { take oral } \\
\text { medication }\end{array}$} & $\begin{array}{l}\text { Cefazolin } \\
\text { or } \\
\text { Ceftriaxone } \\
\text { or } \\
\text { Clindamycin }\end{array}$ & $\begin{array}{c}1 \mathrm{~g} \mathrm{IM} \\
\text { or IV } \\
\begin{array}{c}600 \mathrm{mg} \mathrm{IM} \\
\text { or IV }\end{array}\end{array}$ & $50 \mathrm{mg} / \mathrm{kg}$ IM or IV \\
\hline & & & $\begin{array}{l}\text { Cephalosporins should } \\
\text { not be used in pts with } \\
\text { history of anaphylaxis, } \\
\text { angioedema, urticaria } \\
\text { with penicillin or } \\
\text { ampicillin }\end{array}$ \\
\hline Table 4 & affirmed Recc & mended $R e$ & nen, $2017^{23,24}$ \\
\hline
\end{tabular}


In a study conducted by Roberts et al. in children in 1997 the following incidences of bacteraemia was noticed following various dental procedure. ${ }^{19}$

In our study, with regards to the type of antibiotics, the most preferred was oral amoxicillin, while the most preferred route was oral. There seems to be a major confusion, regarding the type and the antibiotics preferred among the dentists. In a study conducted by Dajani et al. in 1997, it was reported that standard prophylactic regimen for certain dental procedures was 2.0 grams amoxicillin orally 30 - 60 minutes before procedure.9, 20 Dajani and colleagues have also reported that 2 grams of amoxicillin provides several hours of antibiotic coverage. ${ }^{21}$

In 2017, The ADA has reaffirmed the recommended regimen as follows. ${ }^{23}, 24$ Regarding being equipped with the cardiac care in the dental clinic, and the importance of basic life support and advanced life support, there is not much awareness spread among dentists. Emergency cardiac care includes all responses that are required to deal with sudden and life-threatening events affecting the cardiovascular, cerebrovascular and pulmonary systems. It specifically includes. ${ }^{25}$

- Recognition of any early warning signs of heart attack and efforts to prevent complications, reassurance of the victim and prompt availability of monitoring equipment.

- Provision of immediate basic life support at scene when required.

- Provision of advanced cardiac life support at the scene as quickly as possible to defibrillate and if necessary, to stabilize the victim before transportation.

- Transfer of stabilized victim to a hospital so as to provide a definitive cardiac care.

\section{CONCLUSIONS}

Certain type of dental procedures and also some of the specific cardiac lesions are well recognised as requiring provision of antibiotic prophylaxis for the prevention of infective endocarditis. Unfortunately, in some dental management situations there is controversy as to whether or not this should be provided. ${ }^{26}$ Ethically, practitioners, cardiologists and dentists need to discuss the potential benefits and also the harm of antibiotic prophylaxis with their patients before a decision is made about antibiotic administration. ${ }^{27}$ Thus, a further need for extensive awareness amongst the dentists is required, so as to prevent the occurrence of infective endocarditis during dental procedures.

Data sharing statement provided by the authors is available with the full text of this article at jemds.com.

Financial or other competing interests: None.

Disclosure forms provided by the authors are available with the full text of this article at jemds.com.

\section{REFERENCES}

[1] Nomura R, Kokomoto K, Ohara T, et al. Current knowledge among Japanese experienced general dentists regarding prevention of infective endocarditis. Odontology 2018; 106(3):297-305.
[2] Moreillon PP, Que YA. Infective endocarditis. Lancet 2004; 363(9403):139-49.

[3] Lourenc, o S, Caeiro F, Ramos A, et al. Aortic and tricuspid endocarditis due to Streptococcus gallolyticus in an immunocompetent patient with a normal heart. J Cardiol Cases 2010; 1(2):e95-7.

[4] Goldman L, Ausiello D. Cecil Textbook of Medicine. 22 ${ }^{\text {nd }}$ edn. Philadelphia: WB Saunders 2004: p. 956-67.

[5] Nakatani S, Mitsutake $K$, Hozumi $T$, et al. Current characteristics of infective endocarditis in Japan: an analysis of 848 cases in 2000 and 2001. Circ J 2003; 67(11):901-5.

[6] Nakatani S, Mitsutake K, Ohara T, et al. Recent picture of infective endocarditis in Japan-lessons from cardiac disease registration (CADRE-IE). Circ J 2013; 77(6):155864.

[7] Nakagawa T, Wada H, Sakakura K, et al. Clinical features of infective endocarditis: comparison between the 1990s and 2000s. J Cardiol 2014; 63(2):145-8.

[8] Miyatake K, Akaishi M, Kawazoe K, et al. Guidelines for the prevention and treatment of infective endocarditis (JCS 2003). Cir J 2003; 67(Suppl 4):1039-110.

[9] Dajani AS, Taubert KA, Wilson W, et al. Prevention of bacterial endocarditis. Recommendations by the American Heart Association. Circulation 1997; 96(1):35866.

[10] Wilson W, Taubert KA, Gewitz M, et al. Prevention of infective endocarditis: guidelines from the American Heart Association: a guideline from the American Heart Association Rheumatic Fever, Endocarditis and Kawasaki Disease Committee, Council on Cardiovascular Disease in the Young and the Council on Clinical Cardiology, Council on Cardiovascular Surgery and Anesthesia and the Quality of Care and Outcomes Research Interdisciplinary Working Group. Circulation 2007; 116(15):1736-54.

[11] American Heart Association. Prevention of rheumatic fever and bacterial endocarditis through control of streptococcal infections. Circulation 1955; 11:317-20.

[12] Lauber C, Lalh SS, Grace M, et al. Antibiotic prophylaxis practices in dentistry: a survey of dentists and physicians. J Can Dent Assoc 2007; 73(3):245.

[13] Thompson SA, Davies J, Allen M, et al. Cardiac risk factors for dental procedures: knowledge among dental practitioners in Wales. Br Dent J 2007; 203(10):e21.

[14] Hashemipour M, Baharlooei K, Mohammadi A. Iranian dentist's knowledge of antibiotic prophylaxis guidelines for prevention of bacterial endocarditis. Journal of Dentistry 2007; 8(1):46-57.

[15] Marian AJ, Brugada R, Robetts R. Cardiovascular disease caused by genetic abnormalities. Chap - 82. In: Fuster V, Walsh RA, Harrington RA, et al, eds. Hurst the Heart. Vol 2. $13^{\text {th }}$ edn. New York, NY: McGraw-Hill Publication 2011.

[16] Farrington FH. The incidence of transient bacteraemia following pulpotomies on primary teeth. ASDC J Dent Child 1973; 40(3):175-84.

[17] Baumgartner JC, Heggers JP, Harrison JW. Incidence of bacteraemias related to endodontic procedures II. Surgical endodontics. J Endod 1977; 3(10):399-402.

[18] Scully C, Cawson RA. Medical problems in dentistry. $5^{\text {th }}$ edn. London: Elsevier/ Churchill Livingstone 2005.

[19] Roberts GJ, Holzel HS, Sury MR, et al. Dental bacteraemia in children. Pediatr Cardiol 1997; 18(1):24-7. 
[20] Sroussi HY, Prabhu AR, Epstein JB. Which antibiotic prophylaxis guidelines for infective endocarditis should canadian dentists follow? J Can Dent Assoc 2007; 73(5):401-5.

[21] An updated legal perspective on antibiotic prophylaxis: American Dental Association division of legal affairs. J Am Dent Assoc 2008; 139 Suppl: 10S.

[22] Gould FK, Elliott TS, Foweraker J, et al. Guidelines for the prevention of endocarditis: report of the working party of the British Society for Antimicrobial Chemotherapy. J Antimicrob Chemother 2006; 57(6):1035-42.

[23] Nishimura RA, Otto CM, Bonow RO, et al. AHA/ACC focused update of the 2014 AHA/ACC guideline for the management of patients with valvular heart disease: a report of the American College of Cardiology/American heart association task force on clinical practice guidelines. Circulation 2017; 135(25):1159-95.

[24] ADA. Antibiotic prophylaxis prior to dental procedures. Oral Health Topics 2017.

[25] Guidelines 2000 for cardiopulmonary resuscitation and emergency cardiovascular care supplement: a consensus on science. Circulation 2000; 102(8).

[26] Roberts GJ, Ramsdale D, Lucas VS. Dental aspects of endocarditis prophylaxis: new recommendations from a working group of The British Cardiac Society Clinical Practice Committee and Royal College of Physicians Clinical Effectiveness and Evaluation Unit. 2004.

[27] Oliver R, Roberts GJ, Hooper L. Penicillin's for the prophylaxis of bacterial endocarditis in dentistry. Cochrane Database Syst Rev 2004; (2):CD003813. 